\title{
HPV-infeksjon og celleforandringer hos uvaksinerte kvinner
}

\author{
Ny kunnskap om livmorhalskreft \\ og infeksjon med humant papil- \\ lomvirus (HPV) tyder på at en vak- \\ sine mot ni HPV-typer kan gi en \\ bedre beskyttende effekt enn \\ dagens vaksine.
}

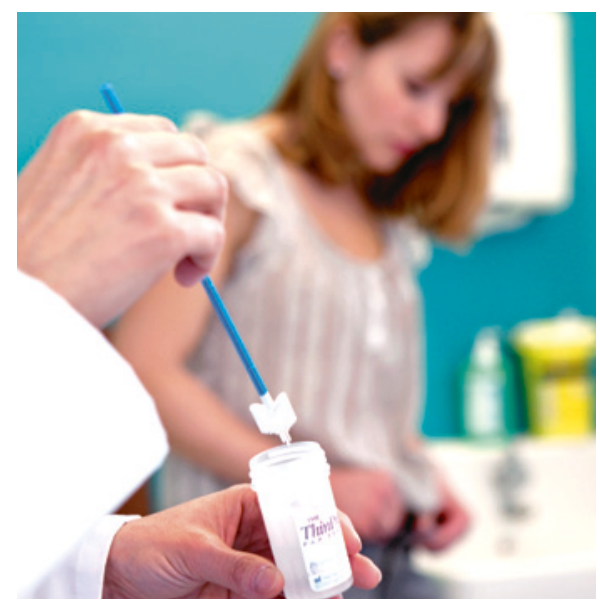

Illustrasjonsfoto: Science Photo Library
Infeksjon med humant papillomvirus (HPV) er nødvendig for utvikling av livmorhalskreft. Viruset finnes i 150 typer, hvorav 12 av dem har vist seg å være kreftfremkallende. Dagens HPV-vaksiner beskytter mot HPV-type 16 og 18, som til sammen forårsaker rundt $50 \%$ av preinvasive celleforandringer og $70 \%$ av krefttilfellene. En internasjonal forskergruppe har nylig publisert en studie der de har undersøkt hvilken rolle ulike HPV-typer spiller i kreftutviklingen (1).

Rundt 10000 kvinner i alderen 15-26 år og nesten 2000 kvinner i alderen 24-45 år som deltok i placebogruppen i tre HPV-vaksinestudier, ble HPV-testet og undersøkt for celleforandringer $\mathrm{i}$ cervix flere ganger $\mathrm{i}$ løpet av fire år. Nesten en tredel av kvinnene i den yngste gruppen testet positivt på ny HPV-infeksjon med én av sju høyrisikotyper. Sannsynligheten for ny infeksjon sank med økende alder. HPV-type 16, 18, 31, 33, 45,52 og 58 var til stede i økende grad med økende alvorlighet av celleforandringer. Opptil $85 \%$ av preinvasive celleforandringer kunne tilskrives infeksjon med en av HPV-typene i en nivalent HPV-vaksine.
- Denne studien er gjennomført blant et utvalg kvinner som ikke er representative for befolkningen, men resultatene er likevel viktige, sier Mari Nygård og Elisabete Weiderpass, som er overleger ved Kreftregisteret. - Dagens screeningprogram er likt for alle kvinner, men måling av HPV-typer kan gi en mer nøyaktig risikovurdering og persontilpasset screening og gi færre uønskede hendelser ved oppfølging og behandling.

- Den største helsegevinsten vil oppnås gjennom HPV-vaksinasjon. En HPV-vaksine mot ni virustyper vil gi $85 \%$ beskyttelse mot preinvasive celleforandringer. Dette er viktige funn som kan få betydning for forebyggingen av livmorhalskreft, både i Norge og internasjonalt, sier Nygård og Weiderpass.

\section{Lise Mørkved Helsingen \\ Tidsskriftet \\ Litteratur \\ 1. Joura EA, Ault KA, Bosch FX et al. Attribution of 12 high-risk human papillomavirus genotypes to infection and cervical disease. Cancer Epidemiol Biomarkers Prev 2014; 23: 1997-2008.}

\section{Akupunktur hjelper lite mot knesmerter}

\author{
Akupunktur med nåler og laser gir ikke mer lindring enn placebo ved \\ kroniske knesmerter.
}

I en nylig publisert studie undersøkte man effekten av akupunktur mot kroniske kneskader som hadde vart i minst tre måneder (1). Nesten 300 pasienter, alle over 50 år, ble randomisert til akupunktur med nåler, akupunktur med laser, akupunktur med narrelaser eller ingen behandling i 12 uker - den siste gruppen var ikke klar over at de var med i en behandlingsstudie. For å minimere skjevheten av forutinntatte holdninger om akupunktur ble et såkalt Zelen-design for kliniske studier anvendt.

Etter 12 uker hadde verken nåleakupunktur eller laserakupunktur bedre effekt på smerter eller funksjonsmål enn narrelaserakupunktur. Nåleakupunktur og laserakupunktur viste noe bedre effekt enn ingen behandling etter 12 uker, men ikke etter 52 uker. De som fikk nåleakupunktur hadde noe bedret funksjon etter 12 uker sammenliknet med dem som ikke fikk behandling, men ikke sammenliknet med dem som fikk narrelaserakupunktur.

- I tillegg til selve resultatene er denne publiserte studien forbilledlig ved å vise hvordan man kan kontrollere for placebo- påvirkning. Både forskere og forskningsetiske komiteer bør merke seg metoden som er anvendt, sier Trond Markestad, professor ved Universitetet i Bergen og forskningskoordinator ved Barneklinikken, Haukeland universitetssykehus.

- Placeboeffekten er gammel kunnskap, men det er først de senere årene vi er blitt oppmerksom på hvor sterk den kan være og hvor vanskelig det kan være å unngå den i intervensjonsstudier, sier Markestad, som var leder i Rådet for legeetikk inntil 2013. Da Rådet uttalte seg om alternativ behandling i 2012, kom det innspill fra flere kilder som mente at akupunktur kanskje kan ha effekt på noen smertetilstander (2).

\section{Tor Atle Rosness}

Tidsskriftet
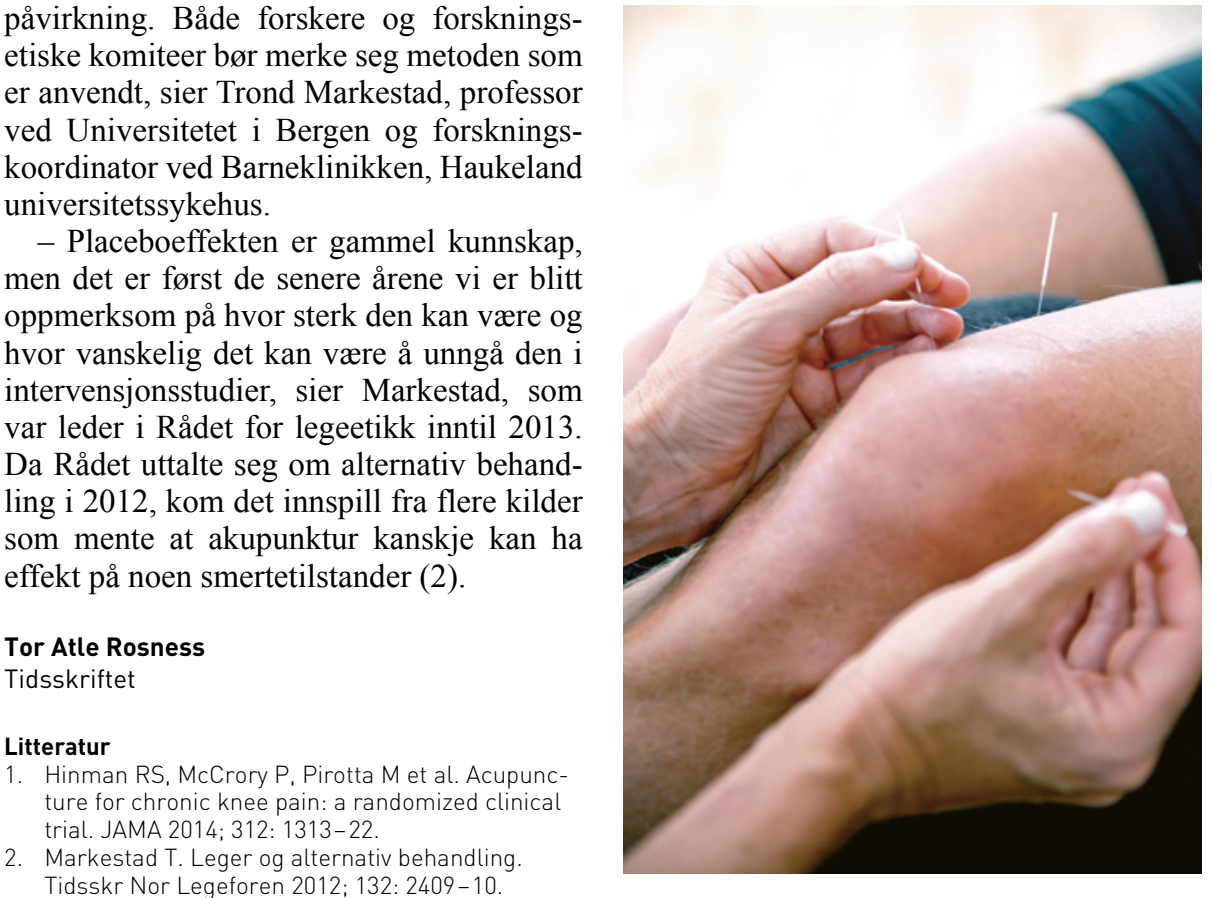

Illustrasjonsfoto: Jens Sølvberg/Samfoto 